\title{
Essay
}

\section{Crafting Cinema in the Buddhist Contemplative Gaze}

\author{
Edward A. Burger \\ Commonfolk Films, Yangon 11111, Myanmar; edward@commonfolkfilms.com
}

Received: 12 March 2019; Accepted: 3 April 2019; Published: 7 April 2019

\begin{abstract}
In this essay, I discuss the evolution of my approach to creating Buddhist contemplative cinema. I begin, by way of personal anecdotes, defining my approach to Buddhist life and the evolution of what I will call the "Buddhist contemplative gaze" - a fundamental shift in perspective shaped by the Buddhist meditation experience. I continue with a discussion of Buddhist art and the distinctive multidimensional quality of the cinema-viewing experience that makes it suitable for celebrating, sharing, and exploring the Buddhist contemplative experience. I trace how my work and life as a Buddhist and a filmmaker come together in this working approach as an artist. The final section of the essay includes reflections on my film, ONE MIND, as an experiment in crafting cinema in the Buddhist contemplative gaze.
\end{abstract}

Keywords: Buddhism and film; Buddhist cinema; contemplative film; devotional cinema; transcendental style in film; contemplative gaze

\section{Introduction}

Once a film is finished, it goes out into the world. You see your film forging relationships with strangers, and it is time to turn toward new ideas. A year or so after I finished my last film, ONE MIND (2015), I was invited to write this essay on the topic of Buddhism and film. At that time, I had been doing little other than thinking about Buddhism and film. I had been playing in that sandbox for a while already, so I was happy to stop and put all this down to paper.

Many of the films we call "Buddhist" films are films about Buddhists. But what I want to talk about here is the art of cinema-making as a Buddhist art like calligraphy, poetry, painting, iconography or architecture. I am looking at cinema itself, the language and forms of cinema, employed as a dynamic art suited to celebrating, sharing, and exploring the Buddhist contemplative life.

I do not want to define anything for anyone else. This is just how I do it. I am a Buddhist and I am a meditator and I am an American artist-a filmmaker. These were once divided, and estranged elements of my life. With this essay, I have pieced together just how and by what process these elements have evolved and united for me into a working approach to Buddhist contemplative cinema. I also want to talk about why I think all of this is worth doing at all. Why it matters.

\section{Shifting Perspectives}

It was right around the time I was heading into college that I started getting interested in the contemplative life. I started to read a lot, and Hesse, Salinger, Maugham, and Kerouac were taking me on epic, soulful adventures. Whether they took me to a living room on the Upper East Side, or a yogi's hut in India, their writing had an incandescence-lit from the inside with inquiry and a spiritual longing. This felt new to me and was the beginning of a profound shift within me, one which illuminated a vast inner world that I was eager to explore.

Looking back, what I found in their writing was a shift in perspective toward a wider view of life. One that respects the entire spectrum of human experience-from joy to pain and everything in between. There is a dark aspect to this world, and we usually encourage one another to turn 
away from that shadow. I was frustrated by the messages around me-from billboards, television, and checkout-counter magazines-that said happiness is out there somewhere, in the opposite direction of the darkness. That you find happiness with your back toward sorrow, pain, longing, and disappointment. There was a whole part of life that felt hidden but full of meaning; taboo but honest. I did not want to abandon that darkness, as if it did not matter, and in me began to boil an eagerness to rebel against that great perpetuating myth about happiness.

That was when, by a miracle of serendipity and some great advice from my academic advisor, I landed in Dr. Harris's course on Buddhism. Everything kind of changed after that. That day I heard the Buddha's life story for the first time, and it was revelatory. I do not think I was really conscious of it at the time, but the Buddha embodied this very sense of rebellion to me. I learned that the Buddha was a prince and that his parents had him cloistered in a palace, hiding him away from the inevitabilities of sickness, old age, and death. But he abandoned palace life and struck out in the night, cutting off his royal locks, the symbol of his princely rank, to enter into the forest to meditate and live the contemplative life. He turned his gaze inward and committed his entire being to inner cultivation.

What he left behind for us is the Dharma-practical and simple, yet evolutive teachings on how to become a kinder and wiser being in this world. I had found my shift in perspective, and with it, a lifetime of creative exploration.

\section{The Contemplative Gaze}

Subhuti, if a bodhisattva should thus claim,

'I shall bring about the transformation of a world,'

such a claim would be untrue. And how so?

The transformation of a world, Subhuti,

the 'transformation of a world' is said by the

Tathagata to be no transformation. Thus is it called

the 'transformation of a world'. (Red Pine 2001, p. 304)

In college, my exploration of Buddhist thought and culture deepened. At the same time, I was getting interesting in art. I had started reading the poems of a Tang Dynasty hermit poet named Cold Mountain. Jack Kerouac affectionately called him a Zen Lunatic (Kerouac 1958) and seemed to identify with his aesthetic sensibility and his rebellious tone, and so did I. Around that time, Bill Porter wrote a book called Road to Heaven (Porter 1993). In it, he said there are hermits like Cold Mountain living in modern China now, just like in the old days. So, after school, off I went on the road to find Cold Mountain myself.

In my first documentary, Amongst White Clouds (2005), you meet the hermit monk whom I still call my teacher today. Shifu taught me how to read scripture, and he taught me to meditate. He is a true mountain monk, with a direct and creative sensibility. He taught me how to sit and explore the forms and capacities of my mind in a way that spoke directly to my own idiosyncrasies and sensibilities as an artist. Every time I hiked down that mountain trail, the world seemed a little different than it did on the way up. And over the many years of meditation practice to follow, in both Chan ${ }^{1}$ and Vipassana traditions, a whole new way of seeing and engaging the world started to emerge within me-a way of seeing I call the "contemplative gaze."

Contemplative gaze means living with an awareness of mind-just that basic recognition that within us is this great mindscape, and what goes on in there defines what goes on out here, in life and how we experience the world. Once we start paying attention to that, taking up a meditation practice

1 I use "Zen" when referring to this tradition of approaching and cultivating the Buddhadharma in general, "Chan" when I am talking about Zen Buddhism in China. 
to strengthen it, we step into the contemplative life. But the contemplative gaze is not an enlightened gaze-it is just a shift in perspective that happens naturally when we do meditation. We may discover ourselves standing anywhere on the spectrum from confused to enlightened, and that does not matter here. What matters is the gaze. With the gaze, you are on the Path. And the Path is what Buddhist contemplatives share regardless of where we find ourselves on it.

First, we turn our gaze inward and discover our capacity to pay attention and observe our own body and mind. We work on increasing the fidelity of that attention, the breadth and depth of observation. At first, every thread of our being rebels. It feels awkward and unnatural. But we learn to stay put, sit still, and stick with it. Slowly, as if a light were turned on, shapes begin to emerge. The forms and structures of the mind and of the self-mechanism gain definition as they emerge from the shadows. Mind becomes something workable, something we can relate to. And we can explore in that space. Like the sun rising over a mountain valley, shadows recede, and there is a lovely stream flowing and some patches of dark forest, a cliffside overlooking a grassy pasture, maybe some questionably menacing creatures are milling about. These are not hallucinations: I am just saying that is what it feels like in there- that richness and detail.

When we stand up and open our eyes, the inner world recedes to the background again, concentration is broken by the world's shower of signals, like from out of a cave into the light of day we go. Over time, though, the contemplative gaze inward becomes so strong and resolute that even as we look outward, we can hold that gaze, unwavering, and carry it out into the world and into our lives. This is quite a miraculous thing, a blossoming of the contemplative gaze. The inner realm and the outer realm unite into a single, unified field of experience. The world suddenly feels rich with meaning. As with the explorations of the inner landscapes, insight is inherent in every perception.

Different Buddhist meditation traditions might define this contemplative gaze in different ways. I practiced Chan meditation in China for many years before that pointed me toward Vipassana. I can only speak to my own personal experience and how complimentary both traditions have been in my own life as a Buddhist practitioner and a Buddhist artist. Chan opened me up to the power of inquiry, vulnerability and the nature of mind-its fundamental spatial qualities. Vipassana turned me toward understanding body, form, structure, and the self-mechanism.

Regardless of the tradition practiced, by what method you cultivate it, for me, this contemplative gaze is a fundamental shift toward an artistic perspective ${ }^{2}$-from a life lived for what we see, to a life lived for how we see. It is a shift from distraction toward presence. From a reactive relationship with the world toward an illuminating gaze upon the world. This is a definitive contemplative Buddhist experience. We are not talking about states of euphoria or being carried off somewhere. Inherent in this gaze itself is a power to heal and evolve-to move toward buddhahood.

\section{New Art for an Old Path}

When we look at a work of art, we bring our whole being with us in that moment-our karmic baggage body-everything that colors the way we see the world. Art can be like a mirror that reflects back to us who we are in that moment. We see things, but in those things, we see ourselves too; our past, our aggression or our passion relating to that thing, all reflecting back to us. Everything is aglow with this incandescence. And some art calls on us to engage that reflecting itself and deepen it.

A lot of what we create in this world is crafted to distract us-carry us away in emotional reveries. I do not want to dismiss the value of pure entertainment, but I do want to point out this important distinction. Contemplative art is not a distraction, it is an illumination. It gives form to the ineffable, takes it out of the shadows, makes it workable, makes it relatable. The art impulse has always been about giving shape to mystery. From the Buddhist perspective, the mystery is mind itself.

2 Chögyam Trungpa Rinpoche's discussions on this topic are lucid and piercing. I refer often to his book, True Perceptions (Trungpa 2008). 
Traditional Buddhist art forms such as calligraphy, landscape painting, poetry, and story have given shape to the contemplative experience for many centuries. Years ago, I had a book on the Zen Arts that I really loved. And in there was a big, beautiful black and white photo of Ryoanji Rock Garden in Kyoto. A couple years ago, my wife and I went to see that garden. The first glance through the frame of dark timber pillars and roof beams took my breath away. From the viewing-veranda, the precision of the craftsmanship of the whole garden, the angles, the composition, the textures-it is like being in the presence of mind itself. There is a skillful utility of form and means that resonates with the mindscape within us, lights it up, and grounds us in presence and attention. I thought, there has got to be a way to make cinema as elegant but impactful as this.

The distinctive multidimensional quality of the cinema-viewing experience makes it suitable for celebrating, sharing, and exploring the Buddhist contemplative experience as I know it and as I see others living it. I look for inspiration from cinema masters like Andrei Tarkovsky, Werner Herzog, Agnès Varda, and David Lynch, who I think are working with cinema with similar intention. These filmmakers are interested in memory and dreams and ecstatic vision. And they work at such a transcendent depth, working with cinema as a language to express a mysterious and profound inquiry into human experience, that I believe they are edging up on something universal. I do not think any of them would say that they are Buddhist contemplative artists, but in their work, I recognize the contemplative principles that I want to explore though film.

\section{ONE MIND—A Study}

ONE MIND began as a simple documentary project. I lived at the monastery. I filmed everything I saw. But I was sitting meditation with the monks five times a day too, and they were teaching me how to properly live within a Chan monastic community. ONE MIND is an artistic experiment born out of what I learned. My filmmaking approach evolved as my understanding of the dynamics of contemplative life deepened. In post-production, it was sometimes frustrating to work with the earlier footage, which was not imbued with my later, more clarified approach. This showed me how important it is that all dimensions of the filmmaking process cooperate in a well-defined vision that informs each cinema moment. I see in ONE MIND some failures and some successes. It is a study in contemplative Buddhist cinema. Below are four aspects of the filmmaking that I think outline my inspiration and approach.

\subsection{Living Narratives}

The first time I visited Zhenru Chan Monastery I completely fell in love with the place. I had been studying with Buddhists in China for seven years but had not seen anything like this yet. It is basically a big farm. And the red-brick buildings, the creaky wooden floors, the smell of wood-fire from the kitchen, and beautiful, big gardens felt like home to me. The monks there are meditator monks, and you can tell. Life in the meditation hall lends the Chan monk a very distinctive gait, and life there in the mountains, a certain athleticism. This was a farm community for meditators-and I could hardly believe such a place existed in the world. That is where I filmed ONE MIND. Every year at Zhenru, there is a Chanqi winter meditation retreat. Footage from this arduous, wintry lockdown bookends ONE MIND and inspires the entire approach of the film. During the chanqi, the meditation sessions begin with an incredible ritual. I would find out later that it is a stylized adaptation of the Sudhana story from Chapter 39 of the Avatamsaka Sutra. ${ }^{3}$ But when I stepped into this thing, it felt like pure theatre; like a communal performance celebrating and inspiring the contemplative journey.

As the meditators circle the meditation hall's central altar at an ever-quickening pace, four of the senior monks peel away and take a position at one of the corners of the hall. Then, one by one, each

3 In her book, Seeing Like the Buddha, Francisca Cho describes a structural expression of this narrative at Borobudur that is interesting to compare (Cho 2017). 
raises his xiangban - a ritual implement, in the shape of a long wooden sword-high over his head and calls out loud and in a long and drawn-out deep tone:

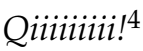

Still walking briskly but hunched at the waist in a deep bow, together we bellow a response:

\section{Qiiiiiiiii!!}

This call and response continues until finally, a signal is struck and with heaving chests, we disperse to find our seats on the meditation bench around the periphery of the hall. Meditation begins.

During a break, warming our feet around a brazier full of glowing coals, I asked a senior monk the meaning of this ritual, and he told me the story like this:

A pilgrim named Sudhana went on a journey to find Maitreya, the Buddha of the Future. Maitreya lived in a fortress, and when Sudhana arrived at the fortress he discovered it had no gate to enter by and no windows. Dumbfounded, Sudhana considered how he could enter the fortress. Just then Manjusri, Bodhisattva of Wisdom, appeared beside Sudhana and grabbed him by the robe with one hand and with his sword of wisdom held high in the other hand, shouted "Qi!"- - and pulled Sudhana through the wall of the fortress and into its inner chamber. There, the young Sudhana stood, face to face with Maitreya, the Buddha of the Future. ${ }^{5}$

It is a classic hero's journey, but distinctly Zen in its telling—-the intensity of the pace, Sudhana's pause, evoking " $q i$ ", the fortress that calls to mind the "gateless gate" and Manjusri with his sword of wisdom breaking through the impenetrable with a "sudden" and piercing wisdom.

Finally, it is up to each meditator to take on the remaining leg of Sudhana's journey, each within the theatre of their own inner mindscape.

I recognized then that I was participating in a kind of lived storytelling. And I looked around the monastery to discover the entire canon of traditional Zen narratives not only being told and passed down between monks and masters but also being performed with the same visceral dimensionality within the everyday life at the monastery. I felt as if I had woken up from a stupor or tuned in to a secret frequency broadcast. I could see P'u Ming's Oxherd Pictures come to life in the monk who tends the monastery oxen. Gong'an like "zen and tea are one flavor" come to life in the traditional tea leaf harvest and the quiet, deliberateness of ceremonial tea drinking before meditation. The "field" of mind and the "thicket" of views all come to life. Even the shape of the monk's bowl speaks a narrative. All of it part of what you could call the "everyday"6 of Chan monastic life there.

To capture the ease and confidence of life there at Zhenru, long suspended shots seemed right—moving past cliché, past simple metaphor, and into the real-time moments where life is being lived in the world of the film. We tend to look at an image and, once recognizing what it is, move swiftly on. The thought is there, "oh, the monk is gardening" and then, what is next? I like a film that stays put and allows for attentive looking and listening. ${ }^{7}$ Not unlike the sustained gaze of observation we cultivate in our meditation practice.

As a meditator and as an artist, I sank a layer deeper into the rich embrace of that life and I knew there was so much to learn, as a filmmaker, from these lived narratives. I was, after all, looking for a way to make a film about this community that does not just show like a portrait, or explain like a slideshow presentation, but a film that is of that experience itself-a film where form and subject are unified.

$4 \quad c^{\prime} i$, 起—arise!

5 I have heard at least a few variations of this story. Many monks insisted it is a strictly oral rendering and cannot be found in any text. Where this stylized version differs from the Avatamsaka narrative, I think, reveals a lot about the character of the Chan approach.

6 For an interesting exploration of the "everyday" in transcendental style in film, see Paul Schrader's, Transcendental Style in Film (Schrader 2018).

$7 \quad \mathrm{Ozu}$ and Bresson and Tarkovsky are wonderful to watch in this respect. Much has been written on this topic. 


\subsection{The Organic Soundscape}

Picture is how we see space, but sound is how we feel it. Zhenru Chan Monastery is in the mountains and remote. The community is mostly self-sufficient, and that magnifies the contemplative atmosphere of the place-adding a layer of sanctuary to it. Our sound designer, Douglas Quin intuited that, and he crafted an immersive world through music and sound-design to reflect that. His soundscape is of the place and is crafted to serve the film's inward trajectory. Working with location audio recordings and instrumentation carefully chosen to be in natural harmony with the environment at Zhenru, he created what I call "musical elements" to evoke a sense of mystery in certain scenes, or as cues in the narrative, especially at shifts in perspective. In some passages, Doug used processing and manipulation of location audio recordings, transforming them, as he describes it, "to reveal their inner workings and worlds of sound within sound". In this way, the ONE MIND soundscape reflects the deepening gaze of meditation, is in tune with the inward journey, and has the feeling of having emerged from within the place itself. Nothing seems to enter from the outside. You step into the world of the monastery and everything you need is there in that space. Like when we sit down to meditate; everything you need is there-breath, body, mind.

If we can slow down and let it, sound can be such a rich and visceral adventure. In cinema, sound invites us to look deeply into long, suspended shots-past simple metaphor, and into a sense of environment, where life is being lived in the world of the film. Wind rustles a bush here, a foot steps there, a monk picks a ripe little tea leaf. The evocation of attention together with the conveyed sense of space make sound integral in establishing the dimensionality of a cinematic image.

\subsection{The Inner Landscapes}

I was not interested in the development of the plot, in the chain of events-with each film I feel less and less need for them. I have always been interested in a person's inner world ... (Tarkovsky 1986, p. 204)

The traditional narratives alive at Zhenru connect us to more than just the life experience there-they speak to real, embodied inner experience too, as with the story of Sudhana's journey. Over the centuries, these are the narratives that survived cultural "natural-selection" to be recounted by Zen masters and rendered by Zen artists as powerful tools to inspire, guide, and communicate inward contemplative experience. But how to make a film in this tradition?

To begin, we need to establish a structure and a grammar that allows for images to belong simultaneously to both the inner and outer realms of experience. This is not new to cinema, and many great filmmakers work in the realm of dreams, memory or ecstatic vision. We can start from there to establish the cinema frame in that gaze, capable of looking upon the unified field of experience that the contemplative traverses. Tarkovsky, Herzog, Malick, Varda, and Lynch guide me.

Firstly, I agree with Andrey Tarkovsky when he says that working within the inner realms is working with life at its most true and so, the images should look true.

I would say that in cinema 'opacity' and 'ineffability' do not mean an indistinct picture, but the particular impression created by the logic of the dream: unusual and unexpected combinations of, and conflicts between, entirely real elements. (Tarkovsky 1986, p. 72)

How we invite the audience to accept an image as dreamscape is in mise en scène, and the "logic" of the edit. And so it is with contemplative cinema. We must edit in the logic of the contemplative gaze. There are certain edits—cued by rhythm of edit or sound, dialogue, or a character's gesture-that are pregnant and powerful, shifting our vision to the inner-landscape view. It is an appropriation of the standard POV shot, but the image belongs to the inner realm —-the mindscape-or to the unified field of experience where the contemplative abides. I think Herzog and his editor Joe Bini have mastered this approach in Encounters at the End of the World (2007).

If a film succeeds in making the audience familiar and comfortable with this shifting between realms of vision, then the contemplative gaze finds its full fruition when we can no longer say for 
certain if what we are seeing in the frame of the cinema screen is the character's gaze upon their world, or upon themselves-their inward gaze. Now we are working with both what the character sees and how the character sees, simultaneously. We are in the contemplative gaze.

We look out at mountain landscapes, or a great sprawl of farmland or a bamboo forest, and these landscapes are nothing other than the character's own inner landscapes. Now the film can play in that space, with all elements of landscape available-like a drop of rain or a drifting cloud, an insect or an ox, swift and fleeting birds.

In ONE MIND, in keeping with the very structural "fortress" element of the Sudhana story, I looked for ways to establish a strong sense of this spatial grammar in the film by using images with a strong feeling of spatial definition-features of architecture and natural landscape. I began by thinking, for example, of the monastery-and by extension, the inner-sanctum of the meditation hall—as Maitreya's fortress. There is no need for precision here. We are working in atmosphere, not metaphor. ${ }^{8}$ This physical sense of formality, married with moments of closing or closed eyes, images, and sounds of doorways and the impression of moving into and out from spaces sets the groundwork for these shifts in point of view from the internal to the external and back again.

\subsection{Who Is Looking?}

When I consider how to compose an image, I think of how it will live in the frame of the cinema screen. That box of light on the wall is a portal into a world the filmmaker creates. Beyond the frame extends an entire reality; there is space there, and time too. When we approach cinema in the contemplative gaze, and we are working with the structural, formal voice of the film, the cinema-space comes alive in its original, true power. It brings to the fore something innate and primal to cinema itself, and because this cinema-space shares so much in qualities with mind itself, these cinema images evoke a very mysterious effect in the viewer. A kind of resonance occurs between the cinema-space and the inner landscape of the viewer themselves. It opens us up to that sense of space within us, and we feel grounded in that sense of being awake inside. I think this is Dorsky's "alchemy" - the union of materiality and subject matter he so eloquently describes in Devotional Cinema (Dorsky 2014, p. 25).

Within this formality, established by visual and audial shaping, the frame-and I mean the cinema screen itself-is energized, empowered as a reference point, to establish a point-of-view. The question who is looking? emerges.

In the case of ONE MIND, establishing this grounding in form, and not presenting a character arc to follow, is intended to shift the perspective of the film away from a reactive posture and away from emotional absorption and distraction-not to leave you hanging there in some kind of void but to settle into the gaze itself. The viewer is free to respond to the film's subject-as nature intends we do-but grounded in the contemplative gaze, we experience ourselves in that scene.

And so, cinema mirrors meditation. More often than not, films ignore this formal quality of the cinema-space and use it simply as a void to fill with story. It can even sometimes be imbued with an aggressive point of view, calling us to respond emotionally, dramatically, and get carried away in the plot, wandering in a web of impulses. But here we are crafting cinema in the image of Buddhist contemplative values, so we engage this quality of film to find our footing and ground ourselves in the mindscape within us like a watchtower from whence we can relate to our unfolding life with illumination and an intention toward healing insight.

The larger structure of ONE MIND is meant to enforce this gaze. My partner and co-writer of ONE MIND, Agnes and I were very deliberate about the grammar of the opening text and chapter text. Maitreya is talking to you. You are the "Young Pilgrim":

8 Tarkovsky explores this sometimes subtle delineation in Sculpting in Time (Tarkovsky 1986). 
Young pilgrim,

Do not turn away from

the unruly ox that runs wild

in the forest of your mind. (ONE MIND 2015)

Throughout the film, too, are nods to this grammar. There are images where the inner landscape of the frame is meant to be for you. Especially the ox. This is a deliberate shift in the grammatical structure.

Some people tell me the quiet scenes of domestic monastic life ease them into a calm and easy rhythm. Others feel ill-at-ease listening to the sound of the razor scraping over the monk's freshly-shaved head. I feel in that case that I got something right.

People sometimes say ONE MIND does not have a plot. But I like to think it does. It is just that the plot is not happening inside of the film, it is happening inside you. In ONE MIND, you are the Pilgrim Sudhana. The scenes you are gazing upon are the inner landscapes of a very special, deliberate spiritual community of meditators living in the mountains of Jiangxi Province. But the journey is all yours.

I want ONE MIND to connect the viewer to the challenges of deep contemplative practice- - that an authentic contemplative life-like we see at Zhenru - is not all peace and happiness. We are Buddhists, not buddhas! These men are struggling the same as we struggle. And while I think we owe them a great respect as people who have chosen to take this struggle on with the entirety of their being and the whole of their precious life, they want us to plant our feet and stay put and look life in the eye as they do, too. I hope that ONE MIND, as a viewing experience, invites each viewer into this very whole and authentic posture toward life. As I went searching for it many years ago.

\section{Conclusions}

At Zhenru, I discovered a commitment to contemplative life on a community level, where all things reflect those basic contemplative values of insight and illumination. As a whole, this kind of monastery is a microcosm for what community can look like when we choose to take on that shift in perspective together and craft our environment in the image of those values, to tell those stories to one another and move toward that vision together. Capturing that in film meant I had to look not only at what these monks live but how they live. And cinema was a perfect vehicle for that because with cinema, I could show you the place and the people as they appear in the contemplative gaze.

The contemplative life is about living life as we live in meditation. Showing up, and staying put. Grounded, not distracted. Inquiring, not averse. Illuminating, not reactive. So, I see contemplative Buddhist art, and cinema included, as a profound kind of protest against our own confusion. And by extension, against the status quo of suffering and abuse in our world born of that collective confusion. It is a radical thing to turn one's gaze within.

All stories are worth being told, joyful or painful, gentle or violent. But there is a toxic way to tell a story and a healthy way-with an open heartedness and an intention toward reconciliation with darkness and joyfulness. And I think this is the greatest gift that art can give us. It empowers us to relate to ourselves in a more authentic way and when we can do that naturally, we begin to heal, and when we heal, we evolve.

Years ago, at a monastery in the north of China, a close teacher of mine ${ }^{9}$ said to me: $A$ buddha is a being, like you or I, who has awoken from the dream of ignorance. That makes us all dreaming buddhas. Much is written about how to tackle dreams in cinema. But how to tackle the dream? We can approach cinema with the same techniques as Tarkovsky or Herzog. We can carry the audience along on a trip into the inner landscapes. And that is really great cinema, but it is not Buddhist contemplative cinema. What makes it Buddhist is in the recognition of the big dream and the aspiration to wake up.

9 Ven. Ming Ying, who at that time was the senior prior at Bailin Chan Monastery. 
Once we make this vow, we step into a life with new intentions. All manner of evils are committed in the misguided yearnings of an unfulfilled, fractured heart. Wholeness, though, is the foundation for kindness. And that is why all of this matters-art, cinema, meditation. Art is not all about creating things, it is also about learning to see with an artful gaze. Learning to look.

Funding: This manuscript received no external funding.

Acknowledgments: Cinema is my language of choice, and not so much words. This being the case, I could not have completed this essay without the help of my wife, Agnes Lam, whose discerning eye herds in my unruly creative ramblings like so many stray cats. Second, I would like to thank Kate Freed and her foundation, whose financial support allows me the time and energy necessary for important projects like this one. Also I want to thank all of the donors and crowdfunding contributors who supported the production of my documentary, ONE MIND. Without their confidence and support I could not have stepped into the deep explorations of contemplative cinema that shaped that film and the ideas in this essay.

Conflicts of Interest: The author declares no conflict of interest.

\section{References}

Amongst White Clouds. 2005. Directed by identifying-text-removed. Calgary: Cosmos Pictures. Cho, Francisca. 2017. Seeing Like the Buddha. Albany: State University Press.

Dorsky, Nathaniel. 2014. Devotional Cinema. Berkeley: Tuumba Press.

Encounters at the End of the World. 2007. Directed by Werner Herzog. Silver Spring: Discovery Films.

Kerouac, Jack. 1958. The Dharma Bums. New York: Viking Press.

ONE MIND. 2015. Directed by identifying-text-removed. Wooster: Commonfolk Films, LLC.

Porter, Bill. 1993. Road to Heaven. Berkeley: Counterpoint Press.

Red Pine. 2001. The Diamond Sutra. Washington: Counterpoint.

Schrader, Paul. 2018. Transcendental Style in Film. Oakland: University of California Press.

Tarkovsky, Andrey. 1986. Sculpting in Time. Translated by Kitty Hunter-Blair. Austin: University of Texas Press. Trungpa, Chögyam. 2008. True Perception. Edited by Judith L. Lief. Boulder: Shambhala Publications, Inc.

(C) 2019 by the author. Licensee MDPI, Basel, Switzerland. This article is an open access article distributed under the terms and conditions of the Creative Commons Attribution (CC BY) license (http://creativecommons.org/licenses/by/4.0/). 